\title{
Global dynamics of socio-environmental crisis Dangers on the way to a sustainable future
} Dinâmica global da crise socioambiental Perigos no caminho para um futuro sustentável Dinámica global de la crisis socioambiental Peligros en el camino hacia un futuro sostenible

\begin{abstract}
Today we are living in the midst of an advancing socio-environmental crisis on a planetary scale. Barriers to a sustainable future - as a positive solution to that crisis - have accumulated. Globalization and capitalist transnational power have worsened social and environmental problems, including global climate change, with serious ecological and socio-economic implications, migration and poverty, social inequalities, unemployment, labour exploitation and degradation, accumulation by dispossession, rent and resource extraction. The global danger to peace is multiplied by current militarization, the proliferation of warfare, and the legitimization of wars and military interventions.
\end{abstract}

Keywords: Socio-environmental crisis. Sustainable future. Globalization. Capitalist transnational power.

Resumo: Hoje estamos vivendo em meio a uma crise socioambiental em escala planetária. Acumulam-se barreiras para um futuro sustentável - que seria uma solução positiva para essa crise. A globalização e o poder capitalista transnacional agravaram os problemas sociais e ambientais, incluindo as mudanças climáticas globais, com graves implicações ecológicas e socioeconômicas, migração e pobreza, desigualdades sociais, desemprego, exploração e degradação do trabalho, acumulação por desapropriação, rentismo e extração de recursos. O perigo global para a paz é multiplicado pela atual militarização, pela proliferação da guerra e pela legitimação de guerras e intervenções militares.

Palavras-chave: Crise socioambiental. Futuro sustentável. Globalização. Poder capitalista transnacional.

Resumen: Hoy vivimos en medio de una crisis socioambiental que avanza a escala planetaria. Las barreras para un futuro sostenible, como solución positiva a esa

\footnotetext{
${ }^{1}$ Centre of Global Studies, Institute of Philosophy, the Czech Academy of Sciences (Prague, Czech Republic).

author_biographical_data
}

Civitas, Porto Alegre, v. 19, n. 2, p. 315-336, May-Aug. 2019

Este artigo está licenciado sob forma de uma licença Creative Commons Atribuição 4.0 Internacional, que permite uso irrestrito, distribuição e reprodução em qualquer meio, desde que a publicação original seja corretamente citada. https://creativecommons.org/licenses/by/4.0/deed.pt_BR 
crisis, se han acumulado. La globalización y el poder transnacional capitalista han empeorado los problemas sociales y ambientales, incluido el cambio climático global, con graves implicaciones ecológicas y socioeconómicas, la migración y la pobreza, las desigualdades sociales, el desempleo, la explotación y la degradación de la condición laboral, la acumulación por despojo, la renta y la extracción de recursos. El peligro global para la paz se multiplica por la militarización actual, la proliferación de la guerra y la legitimación de guerras e intervenciones militares.

Palabras-clave: Crisis socioambiental. Futuro sostenible. Globalización. Poder capitalista transnacional.

\section{Introduction}

The dynamics of capitalist globalization have brought about a new dominant role for transnational capital operating globally across geographical, economic, political and social borders, but at the same time influencing social, economic and political conditions within nation-states and in the spaces between them. An important role is played by actions in the form of the transnational practices of transnational corporations, the transnational capitalist class and global consumerism (Sklair, 2002). Global capitalism produces a social relationship of sharp inequality between capital and labour: capital has transformed itself into money flows in global spaces organized in networks of financial transfers, trade, and production, while labour has been partly integrated into global chains of production, and partly excluded or marginalized. As demonstrated by John Smith, global capitalism produces super-exploitation, where production and trade are expressions of the social relations of exploitation between capital and labour. Outsourcing has been a conscious strategy of capital and a weapon against worker unions, depressing wages and intensifying exploitation (Smith, 2016, p. 67). Transnational finance flows and the financial sector not only intervene powerfully in political systems and government institutions, but also in the everyday dimensions of social reproduction, including the quality of human life. The global capitalist, extremely uneven, the relationship between capital and labour has further extended class polarization and social economic inequalities in both developing and developed societies. From a macro-sociological point of view, we can operationalize these complex global social relationships as two parallel social worlds: societies organized within nation-state organizations, and global social spaces and networks created by the actions of transnational actors. These social worlds are in mutual interaction in a complex web of relationships, dependencies, and interdependencies, mutually transforming and exchanging. Harris focused on the crisis of democracy in the contemporary system of global 
capitalism. He stressed the dangerous high-risk consequences: "Contemporary global capitalism creates global poverty, environmental destruction, and political stagnation" (Harris, 2016, p. 16).

\section{Is the talk of risks enough?}

When we talk about the destructive consequences of many risks, we tend to mean the decision-making process. From a technical perspective, risk can be a calculation of the probability and extent of certain events. The calculability of risk is regulated by knowledge and further research. Important factors here are the normative assumptions and values behind the real decisions and political context of power social relations. Two characteristics of global risks and threats are important here: first, through its development, modern civilization has brought about too many negative consequences where risks have global, transnational consequences. Secondly, these manufactured risks are collective and involuntary in their effects. The collectivity of risks means they are institutionalized and miscalculated as externalities (economic externality is a product of modern development and the capitalist rationality calculus). Modern risks are not the outcome of individual autonomous decisions, but rather of collective conflictual relationships with destructive consequences (Beck, 1999; Beck, 2009a). Normative assumptions of profit are set against the prioritization of future generations' security and quality of life. The problem is not knowledge or science as such, but the decisions involved which cause the conflict, and the political context of social-power relationships (Zinn, 2008, p. 25). One of the definitions of global risk made by a risk report to the World Economic Forum this year reads as follows: "global risk is an uncertain event or condition that, if it occurs, can cause significant negative impact for several countries or industries within the next ten years" (World Economic Forum, 2018).

Global risks should be seen not only as things but rather as social conflicts of power. Risks as things are manifested as an alien force, as an externality paid by those who have no power to make or control the decisions producing risks. Nevertheless risks are also traded as a commodity, as a future opportunity for some, who have access to the key decisions about risk-taking and who would profit from it (Beck, 2009b).

Risk as a social conflict relationship stems from unequal interaction between those who decide voluntarily on an action with dangerous consequences, and those who are influenced with and confronted involuntarily with the dangers. The first group of actors, which is a minority, aims for profit, the second group which is the majority, bears the burden of risk-negative- 
destructive consequences. Yet more catastrophic outcomes can lead to global dangers for all. Environmental as well as other, socially destructive, consequences are often long-term cumulative processes and pose risks and dangers for future generations.

In this sense, we should look at risks and negative consequences as real dangers and relational social processes produced in the real world of global capitalist interactions over an extended historical period. These risks operate in an anti-democratic framework of social inequalities, both economic and political. For example, sociological analysis can show how contemporary environmental and financial risks are intensifying social inequalities resulting from the organized irresponsibility of main institutions. This collective complex of relational processes is reflected as the product of the actions of many different agents. At the same time, sociological critics should analyse class inequalities influencing the distribution of risks (Curran, 2016).

\section{Institutional crisis blocking sustainability}

Economic, social, political and environmental risks are political explosives, where basic "primary" social conflict between unequal social actors produces and causes the many "secondary" (often violent) conflicts we observe today. The key points at issue are the mutual interconnection and reinforcement between capitalist expansion, planetary environmental destruction, social and economic inequality, modernization, development, and wars.

It is important to realize the political nature of contemporary global risks and conflicts - notably, that basic institutional systems are not able to manage the problems and risks that they help to produce. Institutions are unable to support actual redirection towards sustainable development; rather, they continue to support a routine based on obsolete and dangerous ideas of industrial-colonial exploitation and false economic growth goals promoting the reproduction of endless prosperity, which is in fact limited to the richest minority getting richer. The vested interests of the power elite win by relying on knowledge and understanding of the global interdependent complex of risky consequences. Today we face truly a global crisis in terms of the magnitude and reach, the extent of social destruction and environmental devastation, and the scale of the means of violence.

\section{Is it enough to speak of "ecological crisis"?}

Looking back at the last third of the $20^{\text {th }}$ century, we can see that, from the 1970s, numerous crises were related to dynamic transformations in 
political-economic, societal and environmental conditions. An important role is played by the "ecological crisis" or global environmental crisis, in which human society's relationship to the environment on a global planetary scale has reached a critical point (Williams, 2015). This ecological crisis is the long-term process of changes connected with human activities influencing the environment and other living species. Environmental processes are dynamic and change over time. Global temperatures and global climate changes are growing quickly. Descriptions of the state of the planet continue to stand in stark contrast to the absence of global decisive action intended to avoid a catastrophic course. In this dynamic, crisis occasions real disasters. Humans have reshaped the landscapes and the habitats of other species in irreversible ways. In a recent report, world scientists warn humanity that we are learning of a worsening in the negative trends destroying the bioenvironmental conditions of our planet, and catastrophic loss of regenerative sources of natural carrying capacity (cf. World Scientists' Warning to Humanity, 2017).

While knowledge and scientific data about hazardous threats to life on this planet are disseminated, the complete environmental impacts of human activity are not always readily discernible. Environmental change takes place in unexpected discontinuities, feedback loops, and cascading effects. The full damage remains hidden with many synergies (The Worldwatch Institute, 2015). We can define the ecological crisis as "anthropogenic". It is not only a biophysical but also a socio-ecological, phenomenon (Angus, 2016, p. 21). And what makes capitalism unique is not that it is in fundamental contradiction with nature; "rather it is the scope and magnitude of this contradiction, such that human activity now threatens the earth system itself" (Robinson, 2014, p. 230). From the 1970s onwards, the political reaction of powerful capitalist interests was to start dismantling the Keynesian system in the name of "limits to growth", which necessitated a new economic dynamic based on deregulation, privatization, globalization, and also included labour precarization. In addition, the relocation of industries as part of the global expansion (transnationalization) of "free market" capitalism, the pro-export growth-oriented industrialization of China and India, and new directions of technological change played an important role. As a result, crises of social and environmental reproduction are closely related to the manifestations of the contemporary configuration of globalized capitalism (Angus, 2016). This configuration negatively influences civilizational formation either in the further degradation of humanity and the planet or in the generation of something new (Suša, 2016, p. 80-81). 


\section{Capitalist crisis-transformations and the magnitude of their social and environmental consequences}

The globalization of capitalism, the collapse of bureaucratic socialism and the accelerated process of the differentiation of the "third world", with a variety of developing countries and their uneven development, but also differentiation between stagnating Western post-industrial countries and the growing newly industrialized "emerging" ones. There is a global long-term conflict between the transnational shift in accumulation and societies organized within a framework of single nation-states. Transnational capitalist power networks have started to dominate economically in the majority of states. Often the sovereignty of global business networks undermines democracy (cf. Robinson, 2004; Sassen, 1998).

Capitalist adaptation to the limits of growth rendered a shift in the strategy of corporations from long-term to short-term profit, from lower risks to higher risks, capital accumulation led to extensive competition and to monopolistic structures. Such crisis-adaptive transformations over the last 45 years also included political revolution from above, taking the form of the restoration of the class domination of capital owners (with free market neoliberalism as the new dominant discourse) and the re-organization of capitalist enterprises, including a growing asymmetric power relationship between capital and labour. Such developments were resulting in many conflicts with social, economic as well as cultural forms of social exclusion. Social exclusions also engender greater political and social distance between the more polarized minority of the rich and the growing majority of wage labour and the unemployed or underemployed. These changes have led to greater polarization of social inequality as a dangerous risk, which fuels sharper social conflict and discussions on global social justice (Hrubec and Bittar, 2017). Extreme class polarization is a global barrier to sustainable development.

In addition, the information technology revolution has facilitated the transnational movement of money, information, and knowledge as capital so that capital flows and networks of exchange in trade and production have enlarged the flexibility of transnational interactions between both economic and non-economic actors. ICT has helped to disseminate the financialization process.

As for the environmental crisis, reduced to an economic calculus of tradable commodities rather than natural resources - mostly through scarcitymotivated manipulations of prices of resources and energy and global financialization - adaptation to limits led to another crisis: disinvestment in 
productive sectors, or in the real economy, in employment and in the public sector, including human development, education, health, and environmental protection. Governments are also under pressure to continue austerity measures with their many socially and environmentally destructive consequences.

These transformations and risks of capitalist globalization have resulted in the deep crisis of the social-economic reproduction of human societies. Globalized financialization led to the domination of mergers and acquisitions and to a debt-based predatory system, with the effect of a decline in industrial capacity in many industrial counties: financial speculation became the principal means to make profits in Europe, in the US, elsewhere in the world, and in the (former real-socialist) East, where socio-economic decline, privatizations and parasitism were connected with the destruction of real productive forces, along with the neocolonial practices of the capital foreign investments, the withdrawal of capital out of countries and the suppression of workers' wages to a relatively low level, with many social consequences in labour exploitation and extreme social inequalities between rich and poor. The destruction of society goes hand in hand with environmental destruction and the plundering of resources in developing and developed countries alike. Social and environmental destructive changes are both consequences of the "process of opening up new markets". The crisis-adaptive transformations of real capitalism led to a systemic manifestation of deep-rooted contradictions in the global economy (North, 2011, p. 16-19). In the framework of global capitalism, in the new global financialization process, we can speak of a hegemonic transition to "neo-imperialist monopoly capitalism where the surplus is imported from the dependent to the financial core or to the investor" (Nitzan and Bichler, 2012, p. 69).

The core crisis problem relates to the main goal of accumulation: to generate financial wealth, the main means of which is the cycle of returning financial wealth back into the financial markets. This vicious circle leads to speculation, with virtual monetary wealth turning into transnational financial flows and its volatility leading to financial crises. Also, these financial risks are generated by globalized debt. The domination of financial capital is seriously deforming the priorities of enterprises, states, science, and research. With the growing risks of global financialization, the risks of macroeconomic and political destabilization also grow. Social problems connected with growing inequalities, labour precarization (and unemployment or underemployment), social exclusion and environmental damage create a feedback effect in productivity and low efficiency for the capitalist system as a whole. Cognitive capitalism, the newest mutation paradigm, is unable to protect the socio- 
economic system from structural instability. According to the political economists Andrea Fumagalli and Stefano Lucarelli, cognitive capitalism is a new regime of accumulation where information technology and knowledge of information, finance, flexibility in production, and flexibilization of the labour force (its precarization), all result in a "new mode of valorization of capital and in a finance-led growth regime based upon the globalization of financial markets" (Fumagalli and Lucarelli, 2010, p. 7, 11). Here, money increases its power of control. It is the triumph of virtual money that is no longer tied to the real economy. Cognitive capitalism is based on the expansion of financial markets, accompanied by an increase in debt and by speculative gambling. Generalized risk in the economy and social reproduction, the unsustainability of growing debt, distorted income distribution, and the loss of productivity together with an enduring uncertainty. This paradigm is characterized by the fact that financial markets and their instrumental knowledge are the motors of accumulation. Financial markets directly influence and condition the process of accumulation and valorization: this marks the passage from commodity money to sign money. Financial markets play the role of the main multiplier, with the distorted redistribution of revenues leading to the privatization of social reproduction.

\section{Un(der)employment and work relations, their social consequences for future sustainability}

The ILO reports steadily growing world unemployment - globally the estimate reaches some 230 million persons within the next five years (ILO, 2013, p. 10-11). Precarization leads to the risk of social conflicts and riots: rising unemployment rates, income inequalities, a decreasing standard of living, low trust in government and politics... are some of the determinant factors of the social risk index (in 46 out of 71 countries, that index has increased). Long-term unemployment - 12 months and more - is also considered an important factor in social decay, with a loss of the human social capacity to work and to engage socially and politically, thereby eroding the living human potential of democracy. Growing youth unemployment is one of the striking empirical indicators of the contemporary capitalist system's complex social crisis - the group aged between 15 and 25 is in danger of long-term work exclusion and precarity: 74.5 million young people aged 15-24 were unemployed in 2013 and the rate is expected to edge up to 13.2\% in 2014 (ILO, 2014, p. 21). According to the latest OECD statistics (OECD, 2018), the youth unemployment rate varies from 4,7\% (Japan) to 53.3\% (South Africa). Global unemployment is rising, driven by increases in emerging 
economies. Vulnerable forms of employment or underemployment remain pervasive. Inequalities in employment opportunities and social discontent persist, resulting in social unrest and migration (ILO, 2017, p. 7-14). The average duration of unemployment has also gone up, especially in developed economies. This makes job searches harder, with labour skills depreciated. Unemployment comes at considerable personal and social costs, such as decreased life satisfaction and stigmatization. The unemployed become less healthy on average than the employed, which increases the need for public health expenditure. Stagnation, with low investment in the real economy and employment, helps to reproduce social inequality, with a dangerous split between a minority which is getting richer and the majority which is getting poorer. Empirical evidence of critical recent social and environmental developmental consequences that escalate exploitation has been put forward by Saskia Sassen. In her Expulsions. Brutality and complexity in the global economy, Sassen shows that the contemporary capitalist economic system is shrinking the space of the economy through brutal restructuring that cuts across a range of economic sectors, while the space of expulsions of social and public services, and people from labour markets or from their native spaces is expanding (Sassen, 2014). Sassen argues that today's socio-economic and environmental dislocations cannot be fully understood in the usual terms of poverty and injustice. They are more accurately understood as a type of expulsion - from one's professional livelihood, from a living space, even from the very biosphere that makes life possible (Sassen, 2014, p. 211). Economic, political, population and ecological conditions produce various forms of migration and human trafficking, thereby also becoming a global problem.

This complex social crisis makes the capitalist system dysfunctional, with social limits to growth reproducing a vicious circle of stagnation. Furthermore, growing social inequality and unemployment subvert the political solutions to the social crisis through governmental interventions funded by progressive taxation, which continues to be opposed by the ruling capitalist power elite. The distribution of rewards is fixed by power, not by the market. According to Guy Standing, inequality grows partly because rent dominates over earnings excavated by powerful privileged groups of owners with political influence. Corporate taxes were reduced; wages stagnated for several decades. The rest results from the privileges and power connected with private ownership. The neoliberal phase of globalization has evolved into rentier capitalism in which more income is going to those possessing physical, financial or "intellectual" property (Piketty, 2014; Standing, 2016). Piketty proposed reformist policies based on taxation changes. Inequality, he claims, stems from the "political 
context" that supported the privatization of public wealth, but he does not see the role of capitalist class interest policies (Piketty, 2014, p. 125). By reducing use value to exchange value, capitalism reaches its own qualitative social limits, which are fixed in the power-based social relations between capital and labour. Indeed, primitive accumulation, extracting financial rent together with exploitation, further divides and divorces human labour from the collective production of common social wealth (Roggero, 2010, p. 360).

\section{Plundering of the planet and the devalorization of environmental resources for the sustainability of life}

There is a widespread belief that capitalism will not survive the environmental crisis and that the system has reached its absolute limits. As early as 1972, the Club of Rome report "The limits to growth" conjectured that we would not run out of minerals and substances in the near future while recognizing that there would be ever higher costs in obtaining them. A recent report to the Club of Rome - four decades after 1972 - points out very clearly that none of the numerous mineral resources that are extracted daily by the "universal mining machine", and which are essential to the functioning of our industrial civilization, will run out in the near future (Bardi and Randers, 2014). Ugo Bardi assumes that the era of cheap mineral resources will soon be over. The existence of large, easily exploitable deposits will be a thing of the past. Their exploitation will be more costly and more energy consuming, and will also produce more waste and have a higher negative environmental impact on the future of civilization imagined as a mineral eschatology. Without natural resources - oil among them - contemporary industrial global civilization cannot function, and these resources are fast being depleted. The growing number of environmental disasters - including cumulative pollution and climate change - will increase the cost of maintaining infrastructures to unsustainable levels. And the impact of a changing climate on food prices will induce riots that will make societies ungovernable. The endless drive for growth and expansion and consumption are so ingrained into the thinking of the corporate and political leaders that environmental action is still considered to be in conflict with the economy and is relegated to inferior status. The challenge is broader than merely technological; the challenge is the world capitalist system.

On the other hand, there is an observation concerning capitalism's ability to adapt and a certain deformed transformative capacity of "creative destruction": capitalism might well be capable not only of adapting to climate change but of profiting from it. 
Capitalism is confronted with multiple crises - economic, social and ecological - but one crisis can sometimes be harnessed to solve, at least temporarily, another. Contemporary financialized global capitalism continues to increase the massive consumption of fossil energy and other natural resources, and the accelerated export of the Western idea of material growth and consumption so typical of global industrial civilization to the rest of the world has brought the planet closer to climate collapse (Koch, 2012, p. 129-130). In contemporary financialized capitalism, reactions to the challenge of ecological crisis mostly take the form of the weapons of financialization in the framework of "the finance-driven accumulation régime" (Koch, 2012, p. 89), shaping a new variety of environmental financial products. Each has its own specific way of functioning and their purpose is to alleviate or spread the rising costs of climate change and the super-exploitation of the environment. There are, for example, catastrophe bonds, which are not linked to the future like standard bonds, but to the possible occurrence of catastrophes (earthquakes or floods). With a growing number of natural disasters due to climate change, catastrophe insurance management has risen to high levels.

The financialization of nature tries to redefine planet Earth in terms of the language of financial capital: nature is divided into "ecosystem services" that can be quantified, measured and, above all, broken into individual units so that a profit can be made from selling rights to these units. Ecosystem service markets trade the right to pollute or destroy. The financialization of nature is thus a symbol of a crisis system and not a solution to the global problems of the planet. Such a flexibilized commodifying model is promoted by projecting the "green economy" or "green capitalism". Daniel Tanuro, in his Green capitalism: why it can't work, shows that the concept of green capitalism relies on the reform of global capitalism, with an image of a new and environmentally friendly mode of capitalism, reformist lobbying trying to resolve risks and conflicts concerning resource depletion, technological innovation support, and better political and institutional bases for environmental protection. According to the concept of green capitalism development, business should produce green techniques and technologies and consumers should use them. Yet, with such a framework, there is no longer any question of modifying social relations. The priority is that people should take personal responsibility for changing their lifestyle. "Class, social inequality, capitalist lobbies, and power structures disappear from the stage as if by magic, in favor of making individuals guilty," says Tanuro (2013, p. 51).

As with resource depletion and planetary plundering, which have escalated due to market valuation through price and profit-seeking by the 
corporate extraction industries and global traders, in the face of catastrophes related to climate change financial business is passively adapting to these ecological limits and disasters, reproducing in parallel its own profit-seeking strategy of "the commodification of the atmosphere" (Koch, 2012, p. 137) while worsening the environmental condition of the planet. Profit accumulation for some through a disaster for many others is generating unsustainability for our industrial civilization. At the same time, it is also worsening the social crisis of inequality and concomitant conflicting developments. Here we have another empirical example of the relational notion of risk understood in the sense of social conflict.

\section{Expulsions in predatory formation}

The extraction of global resources is paralleled by expulsions of living beings from social, economic and physical environmental spaces. Capitalist transformations and deformations expose a system with devastating consequences - social, environmental and political. This predatory formation consists of an organizing logic, which assembles knowledge, interests, and outcomes that go beyond individual corporate or government projects. The sophisticated knowledge that created today's financial instruments is paralleled by the engineering expertise that enables exploitation of the environment. Saskia Sassen describes risks to human life and the wider environment connected with these capitalist developments: "Under the new systemic logic where global corporations dominate the economy, anything or anybody that gets in the way of profit risks being pushed aside or expelled" (Sassen, 2014, p.214). The destructive forces of these risks and conflicts in human environmental conditions include migration and expulsion, forced labour and human trafficking, the destruction of states, civil wars, land expropriation for resource extraction, urban segregation, unemployment, work poverty, degradation of housing, homelessness, etc. There is a global market for land where dominating finances and global corporations pressure states into exploiting land resources. Humans and other living beings are exploited or expelled from their habitats and from the benefits of the global economic system. The indebtedness of many nations causes the impoverishment of people and devastation of land through toxic pollution, land acquisition or water resources depletion (water is used for fracking, cattle raising, and bottled water sales). Global agribusiness replaces crop diversity with monocrops, which lead to a loss of diversified means of survival and the expulsion of millions of families and whole villages from rural areas to city slums. "Growing land acquisition is connected with financializing commodity production from food to minerals 
and metals, which is stimulating speculative investment in land" (Sassen, 2016, p. 210).

The global scale of our environmental destruction boomerangs back and forth across the world and affects places and flows which never contributed to that destruction. The financial investment system does not contribute to the wider development of socioeconomic reproduction, infrastructures, jobs, education, social and health care, or environmental protection - but flows into private enterprises and firms and their capacity for exploitation and extraction, which operate with relative impunity.

\section{Ecocide, militarization, and resource wars}

There is clear evidence that such a dynamic brings more destruction than creativity. The missing global political framework of regulations, such as a $U N$ climate process resulting in a global pact of substance, remains in the realm of utopia. The UN Climate Panel recently reported that emissions had grown by $2.2 \%$ a year on average between 2000 and 2010 (by $1.3 \%$ a year from 1970 to 2010). In 2010-2011, global emissions from the burning of fossil fuels grew by $3 \%$. The most polluting are coal-burning power plants, and there are more than one thousand new such plants under construction worldwide - most of these are in China and India (Stocker, 2014, p. 50). A call for collective responsibility across governments, business, and civil society is vital for controlling emissions and tackling the system of global reliance on fossil fuels and would open the way to revolutionary innovations. Corporate responsibility cannot limit itself to a responsibility towards investor-shareholders' profit while continuing to breach environmental limits. The violence of plundering resources also reveals a dangerous near future in the form of potential geopolitical conflict-wars for scarce resources in the name of profits for some and the mere survival of others. People who are socially, culturally, economically, politically, institutionally or otherwise marginalized are especially vulnerable to climatic change (IPPC, 2014 , p.6). The global influence of financial capital extends far beyond the provision of loans to finance corporate expansion. Financial capital owns or controls the major proportion of the largest transnational corporations. Recognizing climatic change as a product of capitalism, there then follows the question of whether fractions of transnational finance capital can be mobilized to avoid the climate crisis or whether individual agents of capital might be eager to take action on a change of corporate behavior (Murray and Peetz, 2015). A group of 70 companies has called on governments across the globe to step up efforts to tackle climate change and prevent the risks of disruptive climate impacts, appealing for collective responsibility across 
governments, business, and civil society. Such appeals sound good in the media space, but there is a real and powerful interest coalition between energy (petroleum, coal) and defense businesses making a profit on energy production and consumption while at the same time fuelling accumulation through new wars (Nitzan and Bichler, 2004, p. 320). The potential for militarized conflicts is growing globally. For example, world military expenditure in 2012 was $\$ 1,756$ billion, equivalent to $2.5 \%$ of global gross domestic product (Sipri, 2013). Indeed, the petro-military complex is a major contributor to climate change via direct emissions and the promotion of fake solutions, such as carbon trading, and has a strong interest in the militarist imperial policing of territories with fossil fuel resources. In an era of intensified climate change, we are wrangling about how much to devastate the Earth through industrialscale and systemic violence (Helm, 2015). Global production sites, transport, and communications systems and logistic chains are secured by the global military apparatus. Global militarization constitutes "militarized accumulation and weaponization of the world" and "policing global capitalism" (Robinson, 2014, p.207). The cult of violence and the normalization of militarization in everyday life in media spectacles, as transmitted globally, serve to mask insecurity, injustice, exploitation, and repression.

\section{Conclusion}

Short-term interests and exploitation devastating social and environmental conditions on this planet drive most threats: forests are scalped, rivers run dry, species are going extinct, and humans are changing the climate. Institutional systems are programmed to squeeze more resources from the planet. Societies fail to recognize hidden threats and the ability to survive is put in question.

Today the challenge is no longer locally limited ecological reformism: environmental change is global and hard for humans to control. The challenge today is no longer developing pollution abatement technologies and lessening the degree to which resources are wasted - as an adequate answer to the most pressing problems. Can we try to define and measure some of the "absolute limits" to which capitalism is headed in its "creative destruction" but unsustainable dynamic? In the case of climate change, the politics of climate change indicate resistance to change and complexity, with the increasing influence of money on electoral and legislative processes. A combination of denial, short-term thinking, and profit interest is proving hard to overcome. It seems evident that, in the absence of a struggle for revolutionary transformation, alternative civilizational rules and responsible global regulations, which could be both political and moral, the (relatively) long-term future of capitalist self-market- 
regulation-through-destruction may really be connected with the failure of humankind to respond (in a civilized, i.e. non-violent, manner, which is also very important) to the threat of global environmental devastation and social destruction and catastrophe - including war for scarce resources. In the end - sooner or later - a situation will arise in which no adaptation for survival will be possible. Can capitalism survive without life on this planet? How can social and environmental preconditions for the continuity of life on this planet be secured without revolutionary civilizational transformation? There are preliminary principles concerning this transformation. For instance, the creation of an "ecological society", according to John Bellamy Foster, must be based on the wresting of power from the one percent. "A primarily quantitative society must give way to an emphasis on qualitative human relations and a more sustainable relation to the environment" (Foster et al., 2010, p. 119). The key question for practical transformation is always the issue of power. William Robinson demonstrated this using the actual situation of revolutionary practice: global crisis produces opposing protest movements, but seizing power for transformation remains unsolved. Passive revolts are multifaceted and fragmented, susceptible to co-optations, individualism and apolitical practice (Robinson, 2014, p. 222). The dominant power elite seeks a strategy to keep hold of power, using restructurations combined with repression and social control to contain the discontent. In capitalism, the state serves as an institutional means or tool for the facilitation of capital accumulation and the legitimization of social classes' unequal relations.

A significant political goal of any seizure of power should focus on the important struggle to overthrow the dominant power elite's way of thinking - the reproduction of antiquated and dangerous narrow instrumentalism and possessive growthism, which has become unsustainable in the conditions of the contemporary civilizational crisis.

There is a nexus between environmental, economic and social factors which manifests itself at many levels. This nexus should be evaluated in its complexity and in accordance with new sustainable development goals (Uitto, 2016, p.441). We should remove obstacles in the sphere of social consciousness. As an ideology, neoliberalism construed making profit as the essence of democracy, consumption as the only operable form of citizenship, and the irrational assertion that the market solves all problems and also serves as the model for structuring all social relations. Schools and mainstream media as a set of "cultural apparatus" and "public pedagogy" produce mass passivity, conformity, and obedience, transforming citizens into consumers who forget their political and civic rights and interests, who give up their capacity for 
critical reflexivity. A space dominated by corporate powers is molded, where the creativity of political and responsible citizenship is redefined as a narrow set of consumer choices, human individuals are urged to embrace survivalism as isolated persons - obedient consumers and labourers, where the logic of savage market instrumentality is dominant (Giroux, 2014, p. 29). In the process of depoliticization, many people relegated to sites of terminal exclusion are forced to negotiate their fates alone, bearing full responsibility for a society that forces them to shoulder the weight of problems that are not of their own making and for which they are not personally at fault. Social and environmental public problems are being collapsed into a limited and depoliticized register of private issues.

A depoliticized governance model reflects the relationship between capitalist power and democracy where capital is immune to democracy (Streeck, 2014). The governing bureaucracies of states and transnational executive bodies are enclosed in a routine of "authoritarian liberalism" and "collective Bonapartism" (Brunkhorst, 2017, p. 49), where politics is losing its democratic legitimacy because public truth claims no longer have any chance against the reactionary countermovement; elitist and technocratic voices dominate through the power of expert organizations and institutions with weak democratic legitimacy outside the control of parliaments and public opinion. Ordo-liberalism - proclaiming a (strong state) order framing the social market economy, moralizing "market imperfections", and declaring monopoly prevention - is an institutionalized distrust in democracy. Social inequality, which is still growing everywhere, causes political inequality. Such routines of governance stabilize and enhance the technocratic system of no-alternatives at both levels: the national and the transnational (Brunkhorst, 2017, p. 50). The ordo-liberalist German tradition connects with authoritarian liberalism, where the state should be the predominant power in the relationship between market and state. Transnational governance through the ordo-liberal regime of the euro area proves the utility of states as an organized force representing the political form of a free market. Such authoritarian liberalism is the political practice and moralization of economic life, says Werner Bonefeld (2017). The capitalist state is not a neutral guarantor of the public good; its primary role is to facilitate capital accumulation. In post-neo-liberal policies, global elites are pursuing a new round of restructuring, coupled with new modalities of repression and social control, to contain the discontent that austerity generates (Robinson, 2014). Nation-states serve as population containment zones that allow them to sustain a system of differentiated wages and a race to the bottom (Robinson, 2017, p. 186). 
The institutional and political ability to deal with global issues and to manage globalization is weak. The transnational capitalist class uses its power, centred primarily in global economic spaces which condition social reproduction and the social, political and cultural character of capitalist society. The emergence of a functional and effective political structure to solve global risks and negative consequences is blocked by the coexistence of a globalized economy and international system. This political blockage inflicts real harm to significant segments of the world population. Exposed to the hard edge of globalization, populations naturally react against it, seeking to reassert national control. This creates the political conditions under which nationalist, populist leaders can succeed. Such leaders tend to reject the global cooperation and openness needed for real political solutions to social and environmental risks and conflicts. Nationalist proclamations mask the real efforts of dominant forces to conserve the current status quo without the reassertion of democratic national control. They also weaken and prevent truly global political cooperation.

The world is increasingly fluid and multipolar, pushed and pulled by a diverse set of states and non-state actors, by armed groups as well as by civil society. In a bottom-up world, major powers cannot control local conflicts, but they can manipulate or be drawn into them: local conflicts can be the spark that lights much bigger fires. Globalization is a fact. We are all connected.

It seems evident that there can be no peace and prosperity through sustainable social and ecological development without far more cooperative management of global interactions and dangerous dynamics. Especially important is the role of state-governed responsible reactions to the cycle of violence, and to humanitarian and environmental disasters. States should invest in economic and social development, as well as in support of local governance and civic participation, to close off opportunities for various radical groups. The global institutional "gridlock" of paralyzed international cooperation and the lag between global risks and threats and their treatment are recognized as a major problem. This is accompanied by the declining efficiency of international organizations such as the UN, and the democratic deficit and authoritarian traits of many international bodies and supranational organizations, such as the European Council within the European Union, demonstrating a democratic deficit and crisis of representation. Thomas Hale and David Held describe this as "the growing gap between the need for effective global governance and the ability of intergovernmental institutions to provide it" (Hale and Held, 2018, p. 130). Unmanaged global problems, conflicts, and 
risks inflict severe harm to the global population. An example of the harm of such mismanaged interdependence was the 2008-9 financial crisis. This has led to further destabilization and the rise of nationalism. The financial crisis sharpened the divide between working-class voters in industrialized countries, who were hit hard by the events, and other segments of the population. And there is no guarantee that the major powers' interests will shift in a way that counterbalances the institutional paralysis of international cooperation (Hale and Held, 2018, p. 132).

Nowadays, politicians claim to unite around the shared goal of fighting terrorism. Yet terrorism is just a tactic, and fighting a tactic cannot define a strategy. Terrorist groups exploit wars and state collapse to consolidate their power, and they thrive on chaos. What is needed is the institutional reconfiguration of governance, a democratic, legitimate political process and the repoliticization of the state or national decision-making process. Democratization of democracy is needed. Here the question of power is important: as WI Robinson reminds us, confronting the power of global capitalism is inevitable, which means changing the global balance of social class forces (Robinson, 2014, p.223). Neoliberal transformations have brought about historical deformations: the depoliticization of citizen participation, together with authoritarianism. Authoritarian states can easily misuse the fight against terrorism while policing social resistance to the unfair distribution of conflict and risk and simultaneously maintaining that "there is no alternative, forever". The new state political reconfiguration is influenced by the current endemic imbalance between the activism of social movements on the Right and the passivization of the Left, susceptible to co-optation. The new reconfiguration needs a (both socially and environmentally) progressive vision of national sovereignty (Mitchell and Fazi, 2017). To change the system's recent configuration is "to change the dominant logic of the market" and confront the power of global capital through an effective model of renewed cooperation between social movements, parties, and states. It is important to put forward an alternative vision of systemic change (Robinson, 2014, p. 233).

Until now, the global and local political elite have been engaging in routinized stagnation without innovation and a creative search for alternatives; they exhibit disorientation and disability and refuse to hear the voices of citizens from below, of civil society as well as scientists. Who is ready to believe in the future as a mere continuation of this depoliticized stagnation? The economic global elite continues: "greed is good" - this is the message (Stiglitz, 2018). 


\section{Acknowledgement}

This article was written within the framework of the research program "Global Conflicts and Local Interactions" Strategy AV21, The Czech Academy of Sciences.

\section{References}

ANGUS, I. Facing the Anthropocene: fossil capitalism and the crisis of the earth system. New York: Monthly Review Press, 2016.

BARDI, U.; RANDERS, J. Extracted: how the quest for mineral wealth is plundering the planet. Vermont: Chelsea Green Publishing, 2014.

BECK, U. Critical theory of the world risk society. Constellations, Oxford, v. 16, n. 1, p. 10-22, 2009b. https://doi.org/10.1111/j.1467-8675.2009.00534.x

BECK, U. World at risk. Cambridge: Polity Press, 2009a.

BECK, U. World risk society. Cambridge: Polity Press, 1999.

BONEFELD, W. Authoritarian liberalism: from Schmidt via ordoliberalism to the euro. Critical Sociology, Eugene, v. 43, n. 4-5, p. 747-761, 2017. https://doi.org/ $10.1177 / 0896920516662695$

BRUNKHORST, H. Democracy under siege of authoritarian liberalism: remarks on the crisis of national and transnational republicanism in Europe. Global Policy, v. 8, n. 56, p. 44-53, 2017. https://doi.org/10.1111/1758-5899.12489

CURRAN, B. Risks, power, and inequality in the $21^{\text {st }}$ century. London: PalgraveMacmillan, 2016. https://doi.org/10.1057/9781137495570

FUMAGALLI, A.; LUCARELLI, P. Cognitive capitalism as a financial economy of production. Padova: Quaderni Universita di Padova, 2010.

GIROUX, H. Violence of organized forgetting. New York: City Lights Publishers, 2014.

HALE, T.; HELD, D. Breaking the cycle of gridlock. Global Policy Journal, Durham, v. 9 , n. 1, p. 129-137, 2018. https://doi.org/10.1111/1758-5899.12524

HARRIS, J. Global capitalism and the crisis of democracy. Atlanta: Clarity Press, 2016.

HELM, D. The carbon crunch. New Haven: Yale University Press, 2015.

HRUBEC, M.; BITTAR, E. The era of global disputes and mass media distortions. Communication Today, v. 8, n. 2, p. 146-155, 2017. 
ILO. Global employment trends 2013. Report. Geneva: International Labour Office, 2013.

ILO. Global employment trends 2014. The risk of a jobless recovery. Report. Geneva: International Labour Office, 2014.

ILO. World employment. Global and social outlook. Trends 2017. Geneva: International Labour Office, 2017.

KOCH, M. Capitalism and climate change. Basingstoke: Palgrave Macmillan, 2012. https://doi.org/10.1057/9780230355088

MITCHELL, W.; FAZI, T. Reclaiming the state: a progressive vision of sovereignty for a post-neoliberal world. London: Pluto Press, 2017. https://doi.org/10.2307/ j.ctt1v2xvvp

MURRAY, G.; PEETZ, D. Decoupling capital and climate change: what motivates finance capital climate interested investors. In: SPRAGUE, J. (ed.). Global capitalism in Asia and Oceania. Singapore: Routledge, 2015.

NITZAN, J.; BICHLER, S. Dominant capital and the new wars. Journal of WorldSystems Research, v. 10, n. 2, p. 255-327, 2004. https://doi.org/10.5195/jwsr. 2004.304

NITZAN, J.; BICHLER, S. Imperialism and Financialization: A story of a Nexus. Journal of critical globalization studies, Edinburgh, v. 5, p. 42-78, 2012.

NORTH, D. The capitalist crisis and the return of history. Oak Parks, MI: Mehring Books, 2011.

OECD. Youth unemployment. 2018. Available from: 10.1787/c3634 df7-en.

PIKETTY, T. Capital in the twenty-first century. Harvard: Harvard University Press, 2014. https://doi.org/10.4159/9780674369542

ROBINSON, W. I. A theory of global capitalism: Production, class, and state in a transnational world. Baltimore: The Johns Hopkins University Press, 2004.

ROBINSON, W. I. Debate on the new global capitalism. International Critical Thought, v. 7, n. 2, p. 171-182, 2017. https://doi.org/10.1080/21598282.2017.

1316512

ROBINSON, W. I. Global capitalism and the crisis of humanity. New York: Cambridge University Press, 2014. https://doi.org/10.1017/CBO9781107590250

ROGGERO, G. Five theses on the common. Rethinking Marxism. A Journal of Economics, Culture and Society, v. 22, n. 3, p. 357-373, 2010. https://doi.org/10.1080/ 08935696.2010.490369 
SASSEN, S. A massive loss of habitat. New drivers for migration. Sociology of Development, v. 2, n. 2, p. 204-233, 2016. https://doi.org/10.1525/sod.2016.2. 2.204

SASSEN, S. Expulsions. Brutality and complexity in the global economy. Cambridge Mass.: Harvard University Press, 2014. https://doi.org/10.4159/9780674369818

SASSEN, S. Globalization and its discontents. New York: The New Press, 1998.

SIPRI. Yearbook 2013. Oxford: Oxford University Press, 2013.

SKLAIR, L. Globalization: capitalism and its alternatives. Oxford: Oxford University Press, 2002.

SMITH, J. Imperialism of the $21^{\text {st }}$ century. Global superexploitation, and capitalism's final crisis. New York: Monthly Review Press, 2016.

STANDING, G. The corruption of capitalism: why rentiers thrive and work does not pay. London: Biteback, 2016.

SUŠA, O. From civilizational crisis to revolutionary transformation? In: J. P. Arnason; M. Hrubec (eds.). Social transformations and revolutions. Reflections and analyses. Edinburgh: Edinburgh University Press, 2016. p. 76-98. https://doi.org/10.3366/edinb urgh/9781474415347.001.0001

STIGLITZ, J. The post-Davos depression. 2018. Available from: project-syndicate. org/commentary/davos-ceos-tax-cuts-trump-by-joseph-e--stiglitz-2018.

STOCKER, T. F. et al. Intergovernmental panel on climate change, Climate Change 2013. The physical science basis. Cambridge: Cambridge University Press, 2013. https://doi.org/10.1017/cbo9781107415324.023

STREECK, W. Buing Time. The delayed crisis of democratic capitalism. London: Verso Press, 2014.

ZINN, J. O. Social theories of risk and uncertainty. Oxford: Blackwell, 2008.

TANURO, D. Green capitalism: why it can’t work. New York: Merlin Press, 2013.

THE WORLDWATCH Institute. State of the world. Confronting the hidden threats to sustainability. Washington: Island Press, 2015.

UITTO, J. The environment-poverty nexus in evaluation: implications for the sustainable development goals. Global Policy, v. 7, n. 3, p. 441-447, 2016. https://doi. org/10.1111/1758-5899.12347

WILLIAMS, C. Ecology and socialism: solutions to capitalist ecological crisis. Chicago: Haymarket Books, 2015. 
WORLD ECONOMIC Forum. The global risks report 2018. Available from: https:// www.weforum.org/reports/the-global-risks-report-2018. (30 March 2019).

WORLD Scientist's Warning to Humanity: a second notice. BioScience, v. 67, n. 12, p. 1026-1028, 2017. https://doi.org/10.1093/biosci/bix125

Received at: 30 Sept. 2018

Approved at: 15 Mar. 2019

Published at: 30 July 2019

Corresponding author:

Oleg Suša

Centrum globálních studií

Jilská 1

11000 Praha - Czech Republic

OLEG SuŠA <susa@flu.cas.cz>

Senior researcher at the Centre of Global Studies, Institute of Philosophy, the Czech Academy of Sciences (Prague, Czech Republic).

Orcid: https://orcid.org/0000-0002-4432-1506 